\title{
Effect of hyperthermia on the apoptosis and proliferation of CaSki cells
}

\author{
JUMEI ZHOU ${ }^{1,3}$, XIAOWEN WANG ${ }^{3}$, LEHUI DU ${ }^{2}$, LINYUN ZHAO $^{3}$, FENGLIN LEI $^{3}$, \\ WEIWEI OUYANG ${ }^{2}$, YINGYING ZHANG ${ }^{2}$, YUPING LIAO ${ }^{2}$ and JINTIAN TANG ${ }^{3}$ \\ ${ }^{1}$ Oncology Hospital of Hunan Province; ${ }^{2}$ Department of Oncology, \\ Xiangya Hospital of Centre South University, Changsha, Hunan; ${ }^{3}$ Institute of Medical Physics and Engineering, \\ Department of Engineering Physics, Tsinghua University, Beijing, P.R. China
}

Received August 25, 2010; Accepted November 26, 2010

DOI: $10.3892 / \mathrm{mmr} .2010 .401$

\begin{abstract}
Hyperthermia is a promising treatment for human cervical cancer. However, little is known about whether and under what conditions heat treatment exerts tumor inhibition effects on cervical cancer, and the molecular mechanisms behind these cellular responses have yet to be elucidated. We employed the human cervical cancer cell line CaSki as a cellular model and examined the effect of cell apoptosis and proliferation under gradient thermal conditions (43, 45 and $47^{\circ} \mathrm{C}$ for $40 \mathrm{~min}$ ). Heat treatment was found to induce CaSki cell apoptosis and necrosis. Cell cycle analysis showed that cells were arrested in $\mathrm{S}$ phase upon the application of hyperthermia, and MTT analysis revealed that cell viability was also reduced. Of the thermal conditions, $45^{\circ} \mathrm{C}$ exhibited the best induction of apoptosis, while $47^{\circ} \mathrm{C}$ induced direct fierce necrosis. This was further demonstrated by examining the expression level of several key apoptosis-related genes: caspase-3, Smac and Survivin. During apoptosis, caspase-3 and Smac levels were up-regulated, whereas anti-apoptotic Survivin was down-regulated, enhancing programmed cell death. Our results reveal that heating at $\geq 45^{\circ} \mathrm{C}$ induced cell apoptosis and necrosis, and inhibited cell proliferation at both the cellular and molecular levels. These findings support the use of hyperthermia in a clinical setting for the treatment of human cervical cancer.
\end{abstract}

\section{Introduction}

Cervical cancer, which is mainly caused by persistent infection with high-risk human papillovirus, has in recent years become one of the most prevalent gynecological malignant disorders (1-3). At present, the best possible treatment for locally

Correspondence to: Dr Jintian Tang, Institute of Medical Physics and Engineering, Department of Engineering Physics, Tsinghua University, Beijing, P.R. China

E-mail: tangjt@mail.tsinghua.edu.cn

Key words: hyperthermia, CaSki cells, proliferation, apoptosis, cell cycle advanced cervical cancer is a combination of radiation and a chemotherapeutic agent, such as cisplatin $(4,5)$. However, due to tumor resistance and the numerous side effects of chemoradiotherapy, the 5-year overall survival rate is only $52 \%$ (6). To improve the prognosis for cervical cancer, the development of novel innovative drugs or treatments has become the focus of studies in both the academic and commercial fields.

In recent years, hyperthermia has been recognized as a clinical treatment of certain cancers (such as head and neck and cervical cancer) in combination with radiation and/or chemotherapy $(7,8)$. When tumor cells are exposed to high temperatures, the degree of apoptosis and necrosis is increased, as the cells usually exhibit hypersensitivity to radiation and/or chemotherapy followed heat treatment (9-11). Hyperthermia does not have a significant toxic effect on the body compared to radiation and chemotherapy, is performed locally, and is relatively easy to apply $(12,13)$. Thus, it is viewed as a promising treatment of numerous malignant cancers, including locally advanced cervical cancer. Several trials on hyperthermia in cervical cancer treatment have been performed; however, no definite conclusions have been drawn. Elucidating the effect of hyperthermia on cervical cancer would allow the development of ideal treatment methods.

To investigate whether hyperthermia may serve as a practical treatment for human cervical cancer in the clinical setting, and to provide a more theoretical basis in this field, we examined the effect of gradient hyperthermia conditions on a CaSki human cervical cancer cell line. The most significant apoptosis rate as well as the ideal inhibition of tumor cell proliferation were observed under thermal conditions of $45^{\circ} \mathrm{C}$. Furthermore, this effect was demonstrated at the molecular level by examining changes in several key apoptosis-related genes. The results help to elucidate the molecular mechanisms of apoptosis under conditions of hyperthermia in CaSki cells, and aid in the determination of the ideal hyperthermic conditions for the treatment of cervical cancer.

\section{Materials and methods}

Cell lines and heat treatment. The human uterine cervical cancer cell line CaSki was provided by the cell line bank of Peking Union Medical College, and was cultured in RPMI- 
1640 medium (Gibco) containing 10\% (v/v) fetal bovine serum, penicillin $(50 \mathrm{U} / \mathrm{ml})$ and streptomycin $(50 \mathrm{mg} / \mathrm{ml})$ at $37^{\circ} \mathrm{C}$ in $5 \% \mathrm{CO}_{2}$. For heat treatment, exponentially growing cells were seeded in $25-\mathrm{cm}^{2}$ flasks and then incubated in a hot water bath at temperatures of $37,43,45$ and $47^{\circ} \mathrm{C}$ for $40 \mathrm{~min}$. After heat treatment, the cells were recovered under standard culture conditions at $37^{\circ} \mathrm{C}$ in $5 \% \mathrm{CO}_{2}$.

Analysis of apoptotis and necrotis. The percentage of apoptotic and necrotic cells following hyperthermia treatment was detected by flow cytometry using Annexin V/ PI (MultiSciences Biotech Co., Ltd.). After hyperthermia stimulation for $40 \mathrm{~min}$, the cells were incubated in $5 \% \mathrm{CO}_{2}$ at $37^{\circ} \mathrm{C}$ for $24 \mathrm{~h}$. Subsequently, the cells were washed with PBS, digested with $0.25 \%$ trypsin containing $1 \mathrm{mM}$ EDTA, and then added to medium in a $15-\mathrm{ml}$ centrifugal tube. After washing once in PBS, $5 \times 10^{5}$ cells were resuspended with $500 \mu$ l Bind Buffer, then $5 \mu \mathrm{l}$ Annexin V-FITC and $10 \mu \mathrm{l}$ PI were added. After 15 min, flow cytometric analysis was performed with a FACScalibur (Becton Dickinson, USA). Cells with positive labeling of Annexin V and negative labeling of PI were determined to be apoptotic cells, and were located in the lower right quadrant of the dot plot. Necrotic cells were designated as those with both positive labeling of Annexin V and PI and were located in the upper right quadrant of dot plot. Statistical analysis was performed using ANOVA. P-values <0.05 in comparison to the control group were considered significant.

Cell cycle analysis. Cells were exposed to hyperthermal stimulation and prepared in medium as above. After washing once in PBS, $1 \times 10^{6}$ cells were fixed in $70 \%$ ethanol in PBS at $4^{\circ} \mathrm{C}$ overnight. After another wash in PBS, the cells were resuspended in $1 \mathrm{ml}$ RNase $(0.25 \mathrm{mg} / \mathrm{ml})$ for $30 \mathrm{~min}$ at $37^{\circ} \mathrm{C}$, then centrifuged and resuspended in $500 \mu \mathrm{l}$ PI staining solution (PI $0.05 \mathrm{mg} / \mathrm{ml}$ ) and subjected to flow cytometric analysis of DNA content to determine the stages of the cell cycle.

Cell viability analysis. The MTT assay was employed to evaluate cell viability. After hyperthermal stimulation at various temperatures for $40 \mathrm{~min}$, freshly harvested cells were diluted to the appropriate concentration, and $2 \times 10^{3}$ cells were seeded in 96-well microplates in RPMI-1640 medium. The cells were incubated at $37^{\circ} \mathrm{C}$ in $5 \% \mathrm{CO}_{2}$ for $24,48,72$ and $96 \mathrm{~h}$. After incubation, $20 \mu \mathrm{l}$ MTT was added, and the cells were incubated for an additional $4 \mathrm{~h}$ at $37^{\circ} \mathrm{C}$, followed by the addition of $150 \mathrm{ml}$ DMSO. After $20 \mathrm{~min}$, the amount of formazan present was quantified by determining the absorbance at $490 \mathrm{~nm}$. Results were expressed as the percentage of optical density in relation to the control, corresponding to the mean of three experiments.

Western blot analysis of caspase-3, Smac and Survivin. After hyperthermia treatment as above, the cells were harvested at 2, 6, 12 and $24 \mathrm{~h}$ for Western blot analysis. Cells were washed with PBS, digested with $0.25 \%$ trypsin containing $1 \mathrm{mM}$ EDTA, added to medium in a $50-\mathrm{ml}$ centrifugal tube, then lysed in $400 \mu \mathrm{l}$ lysis buffer (20 mM Tris-HCl, pH 7.4, $150 \mathrm{mM}$ $\mathrm{NaCl}, 1 \%$ Triton $\mathrm{X}-100$ with protease inhibitor). After a 20-min incubation at $4^{\circ} \mathrm{C}$, the cell lysates were centrifuged at 14,000 rpm for $15 \mathrm{~min}$. The supernatant was collected and quantified using a Coomassie Protein Assay Reagent kit to ensure an equal amount of protein loading. The samples were then boiled with $4 \mathrm{X}$ loading buffer $(0.25 \mathrm{M}$ Tris, $\mathrm{pH} 6.8$, 40\% Glycerol, 0.4 M DTT, 8\% SDS and 0.04\% Bromophenol blue) for $5 \mathrm{~min}$. The proteins were fractionated by SDS-PAGE and then transferred to a nitrocellulose membrane. After blocking with $5 \%$ skim milk for $1 \mathrm{~h}$, the membrane was incubated with the indicated primary antibodies: Survivin and Smac (1:1,000 dilution; Cell Signaling Technology) and caspase-3 (1:400 dilution; Thermo Fisher Scientific) at $4^{\circ} \mathrm{C}$ overnight. To visualize the specific bands, horseradish peroxidase-conjugated secondary antibodies (Survivin and Smac, 1:2,000 dilution; caspase-3, 1:10,000 dilution) were used. After incubation with ECL reagent, fluorescence signals indicating the protein bands were visualized by exposure to $\mathrm{X}$-ray film (Kodak) for the appropriate time.

Immunocytochemical analysis of caspase-3. Cells were plated on sterile glass coverslips at a density of $1 \times 10^{5}$ cells/well and cultured until reaching $70 \%$ confluence. The cells were then incubated in a hot water bath at temperatures of $37,43,45$ and $47^{\circ} \mathrm{C}$ for $40 \mathrm{~min}$, then recovered at $37^{\circ} \mathrm{C}$ in $5 \% \mathrm{CO}_{2}$ for $24 \mathrm{~h}$. The cells were then fixed in $4 \%$ paraformaldehyde in PBS for $30 \mathrm{~min}$ and permeabilized with $0.1 \%$ Triton X-100 in PBS for 5 min. After being washed with PBS again, the cells were blocked with goat serum for $10 \mathrm{~min}$, then the excess fluid was shaken off and the cells were maintained overnight at $4^{\circ} \mathrm{C}$ with the primary antibody for caspase-3 (1:200 dilution). Next, the cells were washed with PBS and incubated for 40 min with the Envision ${ }^{\mathrm{TM}}$ System (ZSGB-BIO Corp.). Visualization was performed with diaminobenzidine. After washing with water, the samples were dehydrated and covered with a coverslip. The results of staining were quantified by determining the optical density using Leica QWin software (Leica Microsystems Ltd.). Cells were counted in five visual fields under a microscope at a magnification of $\mathrm{x} 400$, and images were captured. Statistical analysis was performed using ANOVA. P-values $<0.05$ in comparison to the control group were considered significant.

\section{Results}

Effect of hyperthermia on CaSki cell apoptosis. To determine the effect of hyperthermia on human uterine cervical cancer, CaSki cells were selected and treated under various thermal conditions $\left(43,45\right.$ and $\left.47^{\circ} \mathrm{C}\right)$ for $40 \mathrm{~min}$. Cells were then harvested for FACS analysis before recovery at $37^{\circ} \mathrm{C}$ in $5 \% \mathrm{CO}_{2}$ for $24 \mathrm{~h}$. Annexin V/PI staining was used to quantitatively determine the percentage of apoptosis cells. As shown in Fig. 1A, the cells were divided into three groups: living cells (Annexin V-negative, PI-negative); apoptotic cells (Annexin V-positive, PI-negative) and necrotic cells (Annexin V-positive, PI-positive). Compared to cells cultured normally at $37^{\circ} \mathrm{C}$, in which no significant apoptotic and necrotic effects were observed, heat treatment at all temperatures resulted in increased numbers of apoptotic and necrotic cells, though to different degrees. Treatment at $45^{\circ} \mathrm{C}$ resulted in the highest percentage of apoptotic cells $(12.82 \pm 1.77 \%)$, whereas treatment at $47^{\circ} \mathrm{C}$ caused the most significant enhancement of necrosis $(39.15 \pm 5.67 \%)$ rather than apoptosis 
A
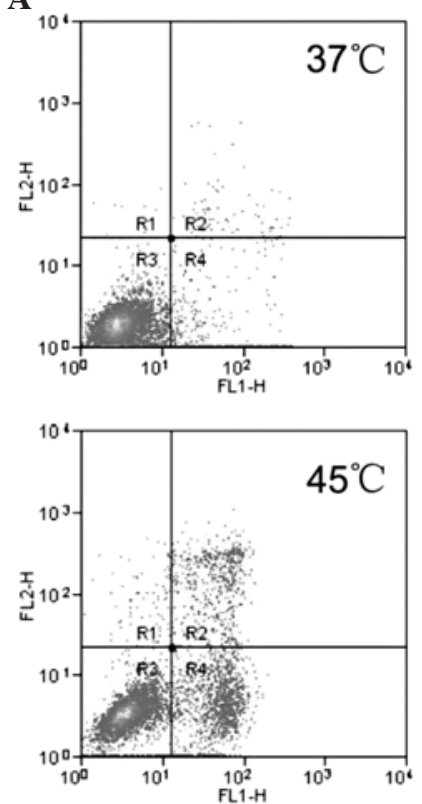

B

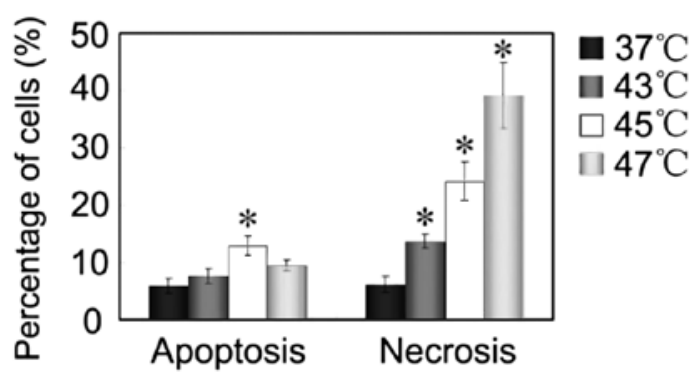

Figure 1. Analysis of apoptosis and necrosis in CaSki cells. (A) FACS analysis of the apoptotic and necrotic cells using Annexin V/PI $24 \mathrm{~h}$ after heat stimulation at 43,45 and $47^{\circ} \mathrm{C}$ for $40 \mathrm{~min}$. Annexin V/PI staining with FACScan dot plot analysis were used to divide the treated and control cells into three groups: living cells (lower left quadrant), necrotic cells (upper right quadrant) and apoptotic cells (lower right quadrant). (B) Statistical analysis of the apoptotic and necrotic cells at $24 \mathrm{~h}$ after heat stimulation. The data obtained from flow cytometry analysis were analyzed using singlefactor analysis of variance. "Statistically significant difference compared to the control group $(\mathrm{P}<0.05)$

$(9.43 \pm 1.04 \%)$ (Fig. 1B). These results indicate that hyperthermia caused the cervical cancer cells to undergo apoptosis, and that the best heat treatment temperature for the induction of apoptosis was $45^{\circ} \mathrm{C}$.

Effect of hyperthermia on the cell cycle. It has been reported that heat shock arrests cells in the S phase, and that S-phase cells are more sensitive to hyperthermia due to the incomplete repair of DNA lethal lesions induced by heat (14). Therefore, to examine whether such S-phase hypersensitivity contributes to CaSki cell apoptosis under hyperthermia conditions, FACS was used to analyze the cell cycle stage distribution of CaSki cells under the indicated heat treatments (Fig. 2A). As shown in Fig. 2B, heat treatment at all three temperatures tested caused the S-phase arrest of CaSki cells. However, cells treated at $45^{\circ} \mathrm{C}$ showed the highest percentage of S-phase cells, consistent with the fact that $45^{\circ} \mathrm{C}$ was found to be the best temperature for the induction of apoptosis in these cells (Fig. 1). Cell viability was also examined by the MTT assay.
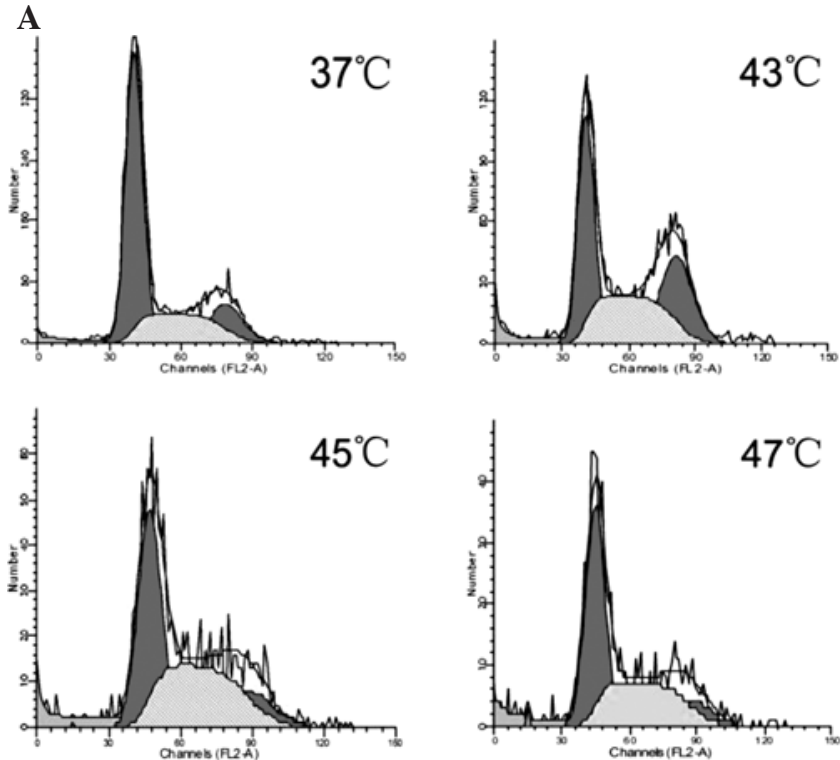

B

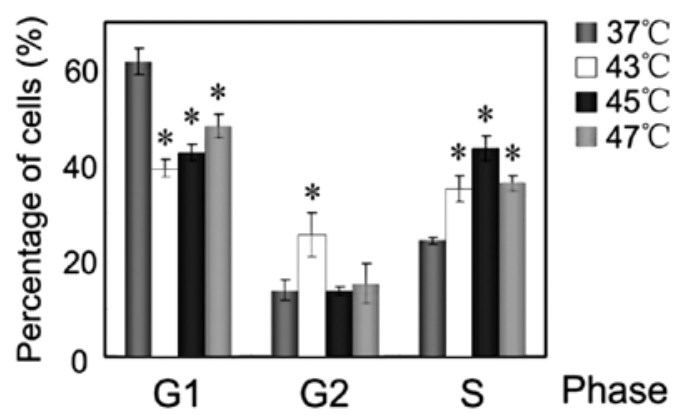

C

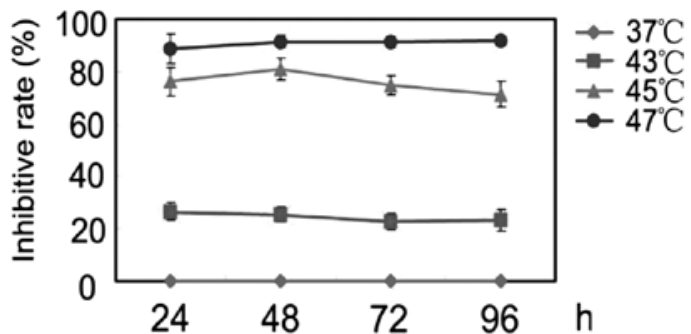

Figure 2. Analysis of CaSki cell proliferation following heat treatment. (A) Flow cytometric analysis of the cell cycle distribution of CaSki cells after 24 $\mathrm{h}$ of heat stimulation at the indicated temperatures. (B) Graph of cell cycle phase distribution after $24 \mathrm{~h}$ of treatment at different temperatures. Values represent the means \pm SD of three experiments. *Statistically significant difference compared to the control group $(\mathrm{P}<0.05)$. (C) Analysis of cell inhibition after hyperthermia treatment. Cell viability was inhibited by treatment at 43,45 and $47^{\circ} \mathrm{C}$ for $40 \mathrm{~min}$ then recovered for the indicated time periods, at which points the amount of MTT formazan product was determined by reading the optical density at $495 \mathrm{~nm}$. Values represent the means \pm SD of three experiments. The three treatment groups were statistically significantly different from the control group $(\mathrm{P}<0.05)$.

CaSki cells underwent heat treatment at various temperatures, and were further cultured under normal conditions for various time periods before measurement of MTT reduction. As shown in Fig. $2 \mathrm{C}$, treatment at 45 and $47^{\circ} \mathrm{C}$ caused significant inhibition of cell viability of up to $\sim 75$ and $90 \%$, respectively, whereas treatment at $43^{\circ} \mathrm{C}$ only yielded a minor inhibitory effect of 20-30\%. This further indicated that hyperthermia at $45^{\circ} \mathrm{C}$ has a satisfactory effect on the inhibition of CaSki cell proliferation and cell death. 


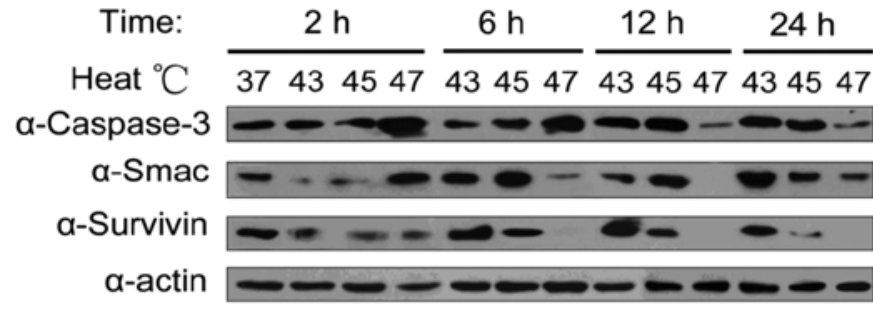

Figure 3. Western blot analysis of the expression of Caspase-3, Smac and Survivin levels at the indicated time points following heat treatment at 43,45 and $47^{\circ} \mathrm{C}$ for $40 \mathrm{~min}$. $\alpha$-actin served as the loading control.

Expression levels of caspase-3, Smac and Survivin following hyperthermia-induced apoptosis. To investigate the molecular basis of the response of CaSki cells to hyperthermia treatment, we examined the expression levels of several key genes involved in the apoptosis signaling pathway.

Caspase-3, a key effector caspase, is activated during apoptosis and targets a spectrum of substrates that are directly involved in the maintenance of cell function and integrity (15). As shown in Fig. 3, hyperthermia at $47^{\circ} \mathrm{C}$ induced significant up-regulation of caspase- 3 during the initial stages of recovery ( 2 and $6 \mathrm{~h}$ ), while at later stages (12 and $24 \mathrm{~h})$, the level of caspase- 3 was significantly down-regulated compared to control cells cultured at $37^{\circ} \mathrm{C}$. This suggests that other cell death programs, such as necrosis, take over the caspase-3mediated apoptotic process (Fig. 1). Of note, hyperthermia at $45^{\circ} \mathrm{C}$ induced the up-regulation of caspase-3 levels starting at $6 \mathrm{~h}$ and sustained up to $24 \mathrm{~h}$, whereas at $43^{\circ} \mathrm{C}$, caspase- 3 was only up-regulated as of $24 \mathrm{~h}$, again indicating that the apoptotic effect at $45^{\circ} \mathrm{C}$ is better than that at $43^{\circ} \mathrm{C}$ (Fig. 1).

We further determined changes in the expression of Smac, an important pro-apoptotic protein released by mitochondria that is required for the activation of effector caspases by inactivating IAPs (16). As expected, hyperthermia at both 43 and $45^{\circ} \mathrm{C}$ up-regulated Smac expression from $6 \mathrm{~h}$ on. By contrast, at $47^{\circ} \mathrm{C}$ there was only a transient increase at $2 \mathrm{~h}$, and no up-regulation over a longer time period, in agreement with the caspase-3 expression profile (Fig. 3).

It was also expected that, upon the initiation of apoptosis, the anti-apoptotic proteins might be down-regulated in conjunction with the progression of apoptosis. Thus Survivin, which inhibits apoptosis by inactivating caspase-3 and caspase-7, was selected as an anti-apoptotic representative. As shown in Fig. 3, the Survivin level decreased sharply at $2 \mathrm{~h}$ under treatment at all temperatures, suggesting a marked response of CaSki cells to hyperthermia. However, only treatment at 45 and $47^{\circ} \mathrm{C}$ caused stable down-regulation from 6 to 24 h (Fig. 3).

To further determine caspase-3 levels after heat shock recovery, immunocytochemistry was employed to examine caspase-3 expression at $24 \mathrm{~h}$ after hyperthermia treatment at the indicated temperatures (Fig. 4A). The results of staining were quantified by determining the optical density. Consistent with the results of Western blotting, hyperthermia treatment at both 43 and $45^{\circ} \mathrm{C}$ up-regulated capase-3, whereas there was no up-regulation at $47^{\circ} \mathrm{C}$ compared to the control group $\left(37^{\circ} \mathrm{C}\right)$ (Fig. 4B).
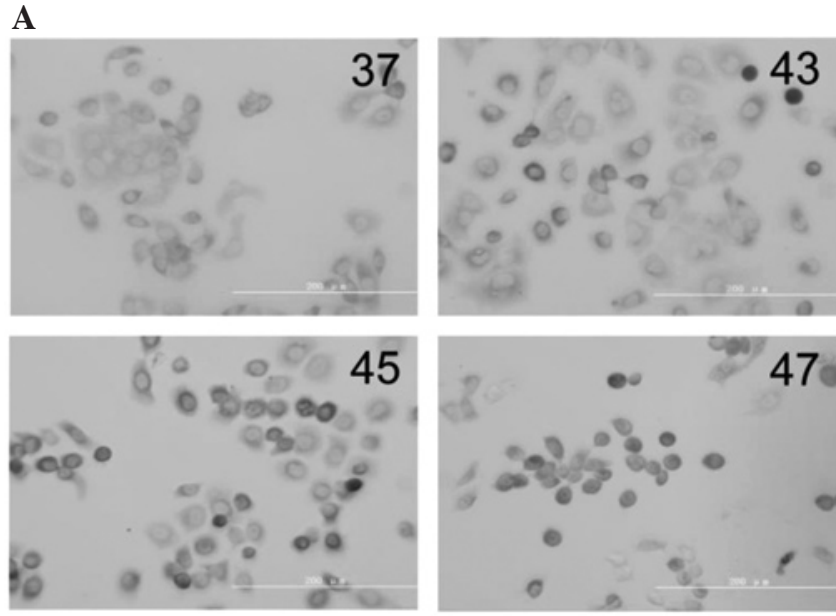

B

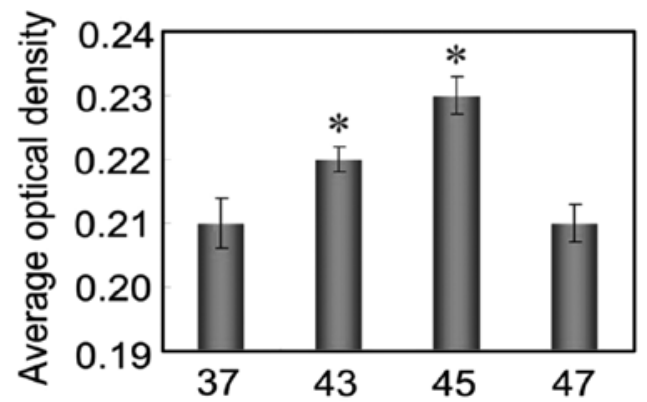

$\left({ }^{\circ} \mathrm{C}\right)$

Figure 4. Immunocytochemistry analysis of caspase-3 expression in CaSki cells after heat treatment. (A) Positive expression of caspase-3 in CaSki cells after $24 \mathrm{~h}$ of hyperthermia treatment at the indicated temperatures. Caspase-3 was predominantly localized in the cytoplasm with little nuclear staining (two-step ICC, x400). (B) Positive expression of caspase-3 analyzed by Leica QWin software. The average optical density at 43 and $45^{\circ} \mathrm{C}$ was statistically significantly different from the control group $(\mathrm{P}<0.05)$.

Taken together, caspase-3, Smac and Survivin all play roles in hyperthermia-induced apoptosis, and the expression profile of these key regulators further suggests that $45^{\circ} \mathrm{C}$ is the ideal temperature for inducing CaSki cell apoptosis.

\section{Discussion}

Hyperthermia was recently suggested as a promising therapy when used in conjunction with radiation and chemotherapy for the treatment of cervical cancer (17-19). To confirm whether heat treatment has an inhibitory effect on cervical cancer and to provide more detailed experimental evidence for this promising clinical therapy, in the present study we employed CaSki cells, a widely used human cervical cancer cell line, as a cellular model and systematically analyzed cell response to a gradient thermal treatment $\left(43,45\right.$ and $\left.47^{\circ} \mathrm{C}\right)$ by examining cell apoptosis, necrosis cycle and viability. We further determined the expression kinetics of several critical apoptosis-related genes (caspase-3, Smac and Survivin) by immuoblotting and immunocytochemistry, in an attempt to clarify the molecular basis underlying the apoptotic response of CaSki cell.

CaSki cells were first subjected to a gradient thermal treatment for $40 \mathrm{~min}$, and the cell apoptosis rate was analyzed 
by flow cytometry after $24 \mathrm{~h}$ of recovery under normal culture conditions $\left(37^{\circ} \mathrm{C}, 5 \% \mathrm{CO}_{2}\right)$. All heat treatments were found to induce cell apoptosis compared to the control group $\left(37^{\circ} \mathrm{C}\right.$ ) (Fig. 1). However, $45^{\circ} \mathrm{C}$ in particular exhibited the best apoptosis-inducing effect, whereas $47^{\circ} \mathrm{C}$ caused significant cell necrosis, which may reflect a sharp stress response, such as protein unfolding and aggregation to high temperature $(20,21)$ (Fig. 1B).

Cell cyle analysis indicated that a significant portion of cells are arrested in the $\mathrm{S}$ phase following hyperthermia treatment, and an MTT assay for cell viability revealed a significant reduction of MTT formazan following heat treatment, indicating an inhibitory effect on cell viability (Fig. 2). It has been well accepted that S-phase cells possess hypersensitivity to hyperthermia, possibly due to incomplete DNA replication causing lethal lesions and subsequent mitotic destruction. In the present study, hyperthermia indeed arrested CaSki cells in the $\mathrm{S}$ phase, which will in turn caused them to be hypersensitive to heat treatment. Further analysis of cell viability showed that, as the temperature increased, the percentage of viable cells decreased. Both 45 and $47^{\circ} \mathrm{C}$ had a satisfactory inhibitory effect on CaSki cancer cells after an initial $24 \mathrm{~h}$ of recovery, and the inhibitory effect persistsed for up to $96 \mathrm{~h}$ of recovery, indicating that an irreversible cell death program had taken effect.

To elucidate the molecular basis underlying CaSki cell apoptosis upon hyperthermia treatment, the protein levels of caspase-3, Smac and Survivin were examined during recovery after heat treatment. Consistent with the CaSki cell apoptotic response, the key apoptosis effector caspase-3 and its upstream activator Smac were both up-regulated after hyperthermia treatment at $45^{\circ} \mathrm{C}$, starting at $6 \mathrm{~h}$ of recovery, which was just ahead of the initiation of apoptosis shown in Fig. 1. Furthermore, the anti-apoptotic factor Survivin was stably down-regulated from 6 to $24 \mathrm{~h}$ of recovery. Notably, treatment at $47^{\circ} \mathrm{C}$ caused an accelerated change in the expression of these proteins as early as $2 \mathrm{~h}$ into recovery. However, when further examined at a time point, the results appeared to be contradictory to the function these molecules during apoptosis. For instance, caspase-3 was significantly reduced at 12 and $24 \mathrm{~h}$ and Smac expression was also down-regulated from $6 \mathrm{~h}$ on. Thus, we believe that when the CaSki cells were exposed to $47^{\circ} \mathrm{C}$ treatment, an immediate thermal stress was sensed, which may have directly cause cell death by protein unfolding and aggregation, rather than by programmed cell death. This notion is further supported by the marked necrosis (Fig. 1) and high inhibition rate (Fig. 2C) observed with treatment at $47^{\circ} \mathrm{C}$.

The present study analyzed the response of CaSki cells to various hyperthermia conditions. The results indicate that apoptosis was induced in CaSki cells by heat treatment, and that $45^{\circ} \mathrm{C}$ may be the ideal temperature at which it should be applied, as supported by evidence at both the cytological and molecular levels. These findings may be used to pave the way for the clinical use of hyperthermia, either alone or combination with radiation and chemotherapeutic agents, for the treatment of human cervical cancer.

\section{References}

1. Oell W, Janicek M and Mirhashemi R: Epidemiology and biology of cervical cancer. Semin Surg Oncol 16: 203, 1999.

2. Nsen K: Toward vaccines against cervical cancer. Curr Opin Drug Discov 42: 255, 2004.

3. Clifford G, Smith J, Plummer M, et al: Human papillomavirus types in invasive cervical cancerworldwide: a meta analysis. $\mathrm{Br} \mathrm{J}$ Cancer 88: 63, 2003.

4. Neoadjuvant Chemotherapy for Cervical Cancer Meta-analysis Collaboration: Neoadjuvant chemotherapy for locally advanced cervical cancer: a systematic review and meta-analysis of individual patient data from 21 randomised trials. Eur J Cancer 39: 2470-2486, 2003.

5. Perez C, Grigsby P, Chao K, et al: Tumor size, irradiation dose, and long-term outcome of carcinoma of uterine cervix. Int $\mathrm{J}$ Radiat Oncol Biol Phys 41: 307-317, 1998.

6. Green J, Kirwan J, Tierney J, et al: Survival and recurrence after concomitant chemotherapy and radiotherapy for cancer of the uterine cervix: a systematic review and meta-analysis. Lancet 358: 781-786, 2001.

7. Valdagni R and Amichetti M: Report of long-term follow-up in a randomized trial comparing radiation therapy and radiation therapy plus hyperthermia to metastatic lymph nodes in stage IV head and neck patients. Int J Radiat Oncol Biol Phys 28: 163-169, 1994.

8. Martine F, Lukas J, Peter C, et al: Long-term improvement in treatment outcome after radiotherapy and hyperthermia in locoregionallyadvanced cervix cancer:an update of the Dutch deep hyperthermia trial. Int J Radiation Oncology Biol Phys 70: 1176-1182, 2008.

9. Moyer HR and Delman KA: The role of hyperthermia in optimizing tumor response to regional therapy. Int $\mathrm{J}$ Hyperthermia 24: 251-261, 2008.

10. Tadateru F, Satoshi N, Kazumi B, et al: Hyperthermia induces translocation of apoptosis-inducing factor (AIF) an apoptosis in human glioma cell lines. Jpn J Neurooncol 70: 319-331, 2004.

11. Norihiko N, Ichiro N, Toshio O, et al: Analysis of heat-shock related gene expression in head-and-neck cancer using cDNA arrays. Int J Radiat Oncol Biol Phys 53: 190-196, 2002.

12. Johannsen M, Gneveckow U, Taymoorian K, et al: Morbidity and quality of life during thermotherapy using magnetic nanoparticles in locally recurrent prostate cancer: results of a prospective phase I trial. Int J Hyperthermia 23: 315-323, 2007.

13. Akihiko M, Katsuyuki K, Takao M, et al: Novel hyperthermia for metastatic bone tumors with magnetic materials by generating an alternating electromagnetic field. Clin Exp Metastasis 24: 191-200, 2007.

14. VanderWaal RP, Griffith CL, Wright WD, Borrelli MJ and Roti JL: Delaying S-phase progression rescues cells from heatinduced S-phase hypertoxicity. J Cell Physiol 187: 236-243, 2001.

15. Gerhardt E, Kugler S, Leist M, et al: Cascade of caspase activation in potassium-deprived cerebellar granule neurons: targets for treatment with peptide and protein inhibitors of apoptosis. Mol Cell Neurosci 17: 717-731, 2001.

16. Chai J, Du C, Wu JW, Kyin S, Wang X and Shi Y: Structural and biochemical basis of apoptosis activation by Smac/DIABLO. Nature 406: 855-862, 2000.

17. Van der Zee J and van Rhoon GC: Cervical cancer: radiotherapy and hyperthermia. Int J Hyperthermia 22: 229-234, 2006.

18. Martine F, Ronald W, Ancac A, et al: Weekly systemic cisplatin plus locoregional hyperthermia: an effective treatment for patients with recurrent cervical carcinoma in a previously irradiated area. Int J Hyperthermia 23: 443-450, 2007.

19. Geetha S, Bert H, Sherko K, et al: Radiochemotherapy combined with regional pelvic hyperthermia induces high response and respectability rates in patients with nonresectable cervical cancer > FIGO IIb ‘bulky'. Int J Radiat Oncol Biol Phys 66: 1159-1167, 2006.

20. Antonio B, Daniela B, Gajanan V, et al: Hyperthermia inhibits cell proliferation and induces apoptosis: relative signaling status of P53, S100A4, and Notch in heat sensitive and resistant cell lines. J Cell Biochem 103: 212-220, 2008.

21. Liang H, Zhan HJ, Wang BG, et al: Change in expression of apoptosis genes after hyperthermia, chemotherapy and radiotherapy in human colon cancer transplanted into nude mice. World J Gastroenterol 113: 4365-4371, 2007. 